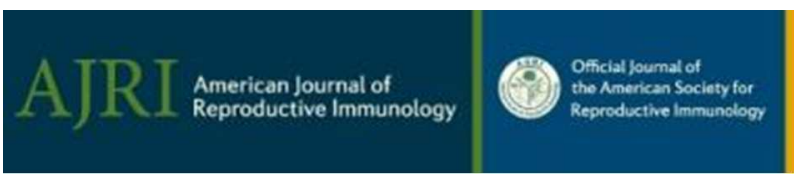

\title{
The regulations and role of circadian clock and melatonin in uterine receptivity and pregnancy - an immunological perspective
}

\begin{tabular}{|c|c|}
\hline Journal: & American Journal of Reproductive Immunology \\
\hline Manuscript ID & AJRI-03-17-054.R1 \\
\hline Manuscript Type: & Special Issue \\
\hline Date Submitted by the Author: & 24-Apr-2017 \\
\hline Complete List of Authors: & $\begin{array}{l}\text { Man, Gene; The Chinese University of Hong Kong, Department of } \\
\text { Orthopaedics and Traumatology, The Faculty of Medicine, The Prince of } \\
\text { Wales Hospital,; The Chinese University of Hong Kong, Department of } \\
\text { Obstetrics and Gynaecology, The Faculty of Medicine, The Prince of Wales } \\
\text { Hospital, } \\
\text { Zhang, Tao; Shenzhen key laboratory of reproductive immunology for peri- } \\
\text { implantation, Fertility Center, Shenzhen Zhongshan Urology Hospital; } \\
\text { Shenzhen Zhongshan Institute for Reproduction and Genetics, Shenzhen } \\
\text { Zhongshan Urology Hospital } \\
\text { Chen, Xiaoyan; The Chinese University of Hong Kong, Department of } \\
\text { Obstetrics and Gynaecology, The Faculty of Medicine, The Prince of Wales } \\
\text { Hospital } \\
\text { Wang, Jianzhang; The Chinese University of Hong Kong, Department of } \\
\text { Obstetrics and Gynaecology, The Faculty of Medicine, The Prince of Wales } \\
\text { Hospital, } \\
\text { Wu, Fangrong; The Chinese University of Hong Kong, Department of } \\
\text { Obstetrics and Gynaecology, The Faculty of Medicine, The Prince of Wales } \\
\text { Hospital, } \\
\text { Liu, Yingyu; The Chinese University of Hong Kong, Department of } \\
\text { Obstetrics and Gynaecology, The Faculty of Medicine, The Prince of Wales } \\
\text { Hospital } \\
\text { Wang, Chi Chiu; The Chinese University of Hong Kong, Department of } \\
\text { Obstetrics and Gynaecology, The Faculty of Medicine, The Prince of Wales } \\
\text { Hospital; The Chinese University of Hong Kong, Li Ka Shing Institute of } \\
\text { Health Science; The Chinese University of Hong Kong, School of Biomedical } \\
\text { Science } \\
\text { Cheong, Ying; University of Southampton Faculty of Medicine, Human } \\
\text { Development and Health } \\
\text { Li, Tin Chiu; Chinese University of Hong Kong, Department of Obstetrics \& } \\
\text { Gynaecology, The Faculty of Medicine, The Prince of Wales Hospital, }\end{array}$ \\
\hline Keywords: & Circadian Rhythms, Immune Response, Melatonin, Placenta, Pregnancy \\
\hline
\end{tabular}


The regulations and role of circadian clock and melatonin in uterine receptivity and pregnancy - an immunological perspective

Gene Chi Wai Man $(\mathrm{PhD})^{1,2}$, Tao Zhang $(\mathrm{PhD})^{3}$, Xiaoyan Chen (MPhil) ${ }^{2}$, Jianzhang Wang (MPhil) $^{2}$, Fangrong Wu (MPhil) ${ }^{2}$, Yingyu Liu (MPhil) ${ }^{2}$, Chi Chiu Wang (PhD) $)^{2,5,6}$, Ying Cheong $(M D)^{4}$, Tin Chiu Li $(M D, P h D)^{2}$

1

Department of Orthopaedics and Traumatology, Faculty of Medicine, The Chinese University of Hong Kong, The Prince of Wales Hospital, Shatin, Hong Kong SAR

Department of Obstetrics and Gynaecology, Faculty of Medicine, The Chinese University of Hong Kong, The Prince of Wales Hospital, Shatin, Hong Kong SAR

Shenzhen Key L2aboratory of Reproductive Immunology for Peri-Implantation, Fertility Center, Shenzhen Zhongshan Urology Hospital, Shenzhen 518045, China

${ }^{4}$ Human Development and Health, University of Southampton Faculty of Medicine, Princess Anne Hospital, Coxford Road, SO16 5YA.

5

Li Ka Shing Institute of Health Sciences, Faculty of Medicine, The Chinese University of Hong Kong, The Prince of Wales Hospital, Shatin, Hong Kong SAR

${ }^{6}$ School of Biomedical Sciences, Faculty of Medicine, The Chinese University of Hong Kong, The Prince of Wales Hospital, Shatin, Hong Kong SAR

Correspondence: Tin Chiu Li, M.D., Ph.D., Department of Obstetrics and Gynaecology, The Chinese University of Hong Kong, 1st Floor, E Block, Prince of Wales Hospital, Shatin, New Territories, Hong Kong. Tel.: +852 2632 2800; fax: +852 2636 0008. Email: tinchiu.li@cuhk.edu.hk

Running Head: Circadian clock role with reproductive immunology 


\begin{abstract}
During normal pregnancy, the mechanism by which the fetus escapes immunological rejection by the maternal womb remains elusive. Given the biological complexities, the immunological mechanism is unlikely to be simply an allograft response in acceptance or rejection of the early pregnancy. Circadian clock responsible for the mammalian circadian rhythm is an endogenously generated rhythm associated with almost all physiological processes including reproduction. There is now growing evidence to suggest that the circadian clocks are intricately linked to the immune system and pregnancy. When perturbed, the role of immune cells can be affected on maintaining the enriched vascular system needed for placentation. This alteration can be triggered by the irregular production of maternal and placental melatonin. Hence, the role of circadian rhythm modulators such as melatonin offers intriguing opportunities for therapy. In this review, we evaluate the complex interaction between the circadian clock and melatonin within the immune system and their roles in the circadian regulation and maintenance of normal pregnancy.
\end{abstract}

Keywords: Circadian Rhythms, Immune Response, Melatonin, Placenta, Pregnancy 


\section{Introduction}

As early as the 1950's, the reasons as to why the fetus can remain immunologically privileged whilst an organ transplant faces rejection, with both the fetus and organ transplant being considered foreign to the host, remains to be completely understood ${ }^{1,2}$. It is envisaged that the early placenta, derived from trophoblastic cells, play an immunologically protective role between the fetus and the maternal host ${ }^{3}$ by creating an immunologically privileged barrier between the maternal circulation and the fetus. The placenta is in fact 'rhythmic', and is now known that clock genes are expressed in the placenta, where the circadian clock controlled transcriptional and translational feedback loops apply within this organ ${ }^{4}$. The disruption of this coordinated process can compromise placental function with an anticipated knock-on effect toward the immune system ${ }^{4}$.

Circadian rhythms organize physiological systems across a temporal order and align them to 24hours environmental cycles. The term "circadian" comes from the Latin circa, meaning "around" and diēm, meaning "day". This is defined as the biological process that displays an endogenous, entrainable oscillation of about 24-hours in an environment with no external constraints. The circadian rhythm has been involved in a number of physiological processes, including sleep/awakening ${ }^{5}$, body temperature regulation ${ }^{6}$, hormone secretion ${ }^{7}$, tissue repair ${ }^{8}$ and cardiovascular function ${ }^{9}$. This system is present in almost every living organism, including plants, non-mammalian and mammalian species. Early works demonstrated striking circadian variation in mice survival rate when challenged with lethal doses of bacteria ${ }^{10,11}$. These studies showed enhanced lethality toward the end of the resting phase, approximately $2 \mathrm{hr}$ before onset of activity (Figure 1). As mice are nocturnal species, therefore, the onset of immune activity occurs when lights were switched off. Although this complicated immunity remains speculative, it does coincide with the period of reduced induction of pro-inflammatory cytokines along with reduced clearance and lethality from bacteria.

In mammals, circadian rhythms are controlled by a central clock located in the suprachiasmatic nucleus (SCN) of the hypothalamus ${ }^{12}$ acting through a coordinated network of molecular circadian clocks in individual cells to generate 24-hours rhythms. This regulation relies on series of transcription and translation feedback loops by a group of circadian genes known as "clock genes." This family of clock genes include the transcription factors BMAL1 and CLOCK; the proteins encoded by genes PER1, PER2, PER3, CRY1, CRY2 and the enzyme casein-kinase-1 epsilon $(C K 1 C)^{13}$. In mammals, a typical transcription and translation feedback loop consist of the two transcriptional activators (Bmal1 and Clock) which form hetrodimers in the cytoplasm and enter the nucleus where they bind the E-box sequences in the promoters of Per (Period) 1, 2 and Cry (Cryptochrome) 1, 2 activating their expression. In the cytoplasm, Per and Cry proteins interact with each other and enters the nucleus to inhibit the activity of Bmal/Clock complexes. The levels of Per and Cry transcripts and their respective protein hence declines. It is thought that Bmal and Clock contribute to the activation of transcription activity of other clock genes through a series of modifications of histones (associated with histone acetyl transferase activity), phosphorylation and dephosphorylation activities ${ }^{14}$. Clock genes are expressed in almost all tissue types, including the heart, liver, muscle, pars tuberalis, and adrenal gland ${ }^{15}$. The circadian synchronization within the cell and between different bodily systems is crucial for the maintenance of health, and the breakdown of this 24-hours clock can lead to pathological conditions involving the neurological, metabolic, cardiovascular, endocrinological and 
gastrointestinal systems ${ }^{16}$. It is hypothesized that the evolution of clock genes in mammals is to anticipate environmental changes related to the photoperiod and seasonal cycles ${ }^{17}$. This enables the body to adapt and respond to various environmental cues, including oxidative stress ${ }^{18,19}$.

Circadian-controlled humoral factors, including melatonin and glucocorticoids, can regulate a myriad of gene expressions and protein activities, which are critical regulators for the circadian clock and immune system ${ }^{20}$. Among these factors, melatonin appears as a key candidate for circadian regulation during female reproduction. Besides being a potent antioxidant, numerous studies have shown the important role of melatonin in follicular and corpus luteal function, pregnancy, puberty, and parturition, indicating its crucial role in reproduction ${ }^{21}$. In addition, not only is melatonin produced by the placenta, it is rapidly transferred from the maternal to the fetal circulation, providing photoperiodic information to the fetus for tissue differentiation and hormonal metabolism².

Hence, the interaction between the immune system and the circadian clock during pregnancy is of vital importance towards fetal growth, development and pregnancy outcome. However, this interaction remains complicated. In this review, we aim to provide an overview, from an immunological perspective, on the roles of circadian clock and melatonin in pregnancy.

\section{The immunity 'clock'}

Studies have revealed that the internal time-keeping system "circadian clock" is responsible for driving the circadian rhythms evident in the immune system ${ }^{23}$. For instance, the recruitment of immune cells (e.g., monocytes, neutrophils, and lymphocytes), antigen presentation, lymphocyte proliferation, and cytokine gene expressions (e.g. TNF- $\alpha$ and IL- 6 ) follows a 24-hour daily rhythm to initiate an acute response to infection ${ }^{24,25}$. Although the circadian susceptibility in host immune response to lethal infection has been recognized for over 50 years ${ }^{26}$, it is until now we have a better understanding of the immune functions being under a circadian control. Work has demonstrated circadian oscillation of nearly every aspect of the immune response (innate and adaptive) ${ }^{20}$. The circadian molecular clocks exist in most immune cells, such as macrophages, dendritic cells, T- and B-lymphocytes, and impacts on host-pathogens interactions, leukocyte transport, activation and deactivation of innate and adaptive immunity responses (Table 1 ).

The central SCN clock was reported to drive circadian rhythms in the expression of adhesion molecules (e.g., ICAM-1 and VCAM-1) on endothelial cells or chemokines/chemokine receptors (e.g., CCL2 and CXCR4) in tissue or leukocytes, which contributes to a time of day-dependent recruitment of leukocytes into the tissues such as the bone marrow and muscle ${ }^{27}$. This regulatory mechanism was further depicted for leukocyte migration by circadian clock in another study ${ }^{28}$. It showed that the frequency of Ly6C $C^{\text {high }}$ inflammatory monocytes in blood, spleen and bone marrow exhibited circadian oscillations. It is suggested that CLOCK/BMAL1 heterodimer negatively regulated expression of CCL2 in monocytes, which then contributed to the circadian oscillations of Ly $6 \mathrm{C}^{\text {high }}$ inflammatory monocytes. This corresponds to the diurnal variations in recruitment of the cells into the sites of inflammation.

Further evidences for circadian oscillations in immunity can be found in the regulation of Tolllike receptors (TLRs) and some of their downstream effector genes ${ }^{29}$. The TLRs are class of 
proteins critical for the innate immunity. They are responsible for recognition of foreign pathogens, enabling the activation of immune cascade against the foreign pathogens. This response was shown to initiate when the CLOCK/BMAL1 heterodimer bound to the promoter of TLR9, thus promoting the expression and function in a circadian manner ${ }^{20}$. Transcriptional analyses in resident peritoneal macrophages have also revealed circadian fluctuations in several aspects of the TLR4-LPS response pathway. A recent study revealed the impact of clock genes on the innate immunity involving the deregulatory circadian effect of PER2 and the upregulation of $\mathrm{TLR9}^{20}$. Silver et al. showed that the disease severity in TLR9-dependent mouse model of sepsis varied with the daily circadian changes in TLR9 expression and function, making the molecular link between circadian and innate immune systems. Similarly, the loss of Per1 prevented excessive innate immune response during endotoxin-induced liver injury ${ }^{30}$, resulting in an elevated level of pro-inflammatory cytokines production. Fibroblasts with abolished Cry $1 / 2$ expression showed an increased in pro-inflammatory cytokine production of nuclear factor kappa-light-chain-enhancer of activated $\mathrm{B}$ cells (NF-KB$)^{31}$. This abolishment would consequently affect BMAL1 to attenuates NF-KB activation by sequestering CLOCK, which controls the acetylation of $\mathrm{p} 65$ for NF-KB transactivation ${ }^{32}$.

Several studies have showed that the circadian clock is also an important regulator of cytokines. In one of these studies, it demonstrated macrophages being isolated from mouse spleen displayed circadian rhythms in TNF- $\alpha$ and IL- 6 secretion when stimulated with LPS at different time points ${ }^{29}$. These cytokine secretion rhythms continue to persist in constant in vitro culture conditions, suggesting that macrophage-intrinsic circadian clock may govern these oscillations. In addition, the temporal variations in serum IL- 6 following LPS challenge were absent in mice with specific deletion of BMAL1 in myeloid cells ${ }^{33}$. With the downstream effect of BMAL1 to activate the transcription of the nuclear receptor REV-ERB $\alpha$ and REV-ERB $\alpha$, which in turns inhibit BMAL1, these rhythmic immune responses to LPS were abolished in REV-ERB $\alpha$-deficient mice ${ }^{33}$. This observation suggests a link among BMAL1, REV-ERB $\alpha$, and IL- 6 production in macrophages upon LPS challenge.

It is widely proposed that circadian clock is a regulatory gatekeeper of immune response and inflammation where oscillatory cycles can be synchronized in- or out-of-phase to regulate the duration, intensity and types of immune response mounted by the body. These oscillatory cycles are generated through either cell-extrinsic or cell-intrinsic mechanisms ${ }^{18}$. The homeostatic trafficking and recruitment of immune cells are largely controlled by cell-extrinsic manner ${ }^{34,35}$. The cell-intrinsic oscillations regulate the rhythmic release of chemokines and adhesion molecules for the trafficking of immune cells for the maintenance of local hemostasis ${ }^{27,34}$. These rhythmic oscillations can be further modified by the external environmental cues and interact with 'chronobiotic' factors, such as melatonin, to exert a myriad of anti-inflammatory and antioxidative effects.

\section{The 'chronobiotic' hormone melatonin modulates immunity and pregnancy outcomes}

Melatonin, also known as $\mathrm{N}$-acetyl-5-methoxytryptamine, is a neuroendocrine hormone produced by the pineal gland $^{36}$, the placenta ${ }^{22}$, the ovary ${ }^{37}$ and is considered to be a 'chronobiotic' hormone with a universal photoperiodic signal, and a molecule with diverse physiological function ${ }^{38}$. Its secretion is regulated by light/dark stimuli and in turn influences circadian rhythm such as sleep. In human, the peak and trough of circadian rhythms for different physiological variables, including blood pressure and sleep/wake cycle, occurs at different 
"clock" times. And under normal light-dark cycle, melatonin concentration would reach a peak during 2 a.m. ${ }^{39}$.

Melatonin is synthesized in higher concentrations within the placenta than the pineal gland ${ }^{21}$. The cyto- and syncytiotrophoblasts from the human placenta contains two enzymes, serotonin $\mathrm{N}$-acetyltransferase and $\mathrm{N}$-acetylserotonin methyltransferase, which can metabolize serotonin to melatonin. Once in the circulation, melatonin can increase phagocytosis, antigen presentation, and exert its anti-oxidative effect on free-radical oxygen species ${ }^{40}$. Melatonin acts through two receptors, MT1 and MT2, which are expressed in circadian pattern and be regulated by endogenous melatonin ${ }^{41}$. Per1 mutant mice exhibits higher plasma and pineal melatonin concentrations during the night (active phase) ${ }^{42}$. The removal of MT2 results in a decrease in Per1 and Cry1 expression in the $\mathrm{SCN}^{43}$. Membrane and nuclear melatonin receptors identified on leukocytes are thought to modulate the proliferative response of stimulated lymphocytes. Studies in mice showed melatonin stimulates the production of IL-4 in bone marrow T-helper cells and of granulocyte macrophage colony-stimulating factor in stromal cells ${ }^{44}$.

In mammals, melatonin is a potent immunomodulator ${ }^{45}$ in terms of circadian regulation on lymphocyte proliferation ${ }^{46}$, enhancing phagocytosis ${ }^{47}$, and stimulate cytokine production ${ }^{48}$. Multiple daily injections of melatonin into the rat pineal gland can significantly promote an increase in macrophage cellularity ${ }^{49}$. Also, natural killer (NK) cells and monocytes were found to be increased when mice were orally fed with melatonin ${ }^{50}$. Whereas in human, the administration of melatonin to healthy subjects promoted the stimulation of NK cell activity ${ }^{51}$. Importantly, melatonin can significantly influence $T$ cell-mediated immune responses ${ }^{52}$. The endogenous melatonin modulates through the interleukin-2/interleukin-2 receptor system on Tcell activation and differentiation, especially for Th17 and Treg cells ${ }^{53}$. NK cells, Tregs, Th1/Th2 ratio and Th17 are all implicated in conditions of reproductive failure such as recurrent miscarriage, recurrent implantation failure and preeclampsia; albeit that the question on causality has yet to be addressed.

It is known that an episodic but consistent rise of maternal melatonin concentration occurs in the third trimester of pregnancy ${ }^{54}$. Melatonin crosses the placenta and blood brain barrier from the maternal circulation to the fetus ${ }^{22}$, and melatonin receptors are widespread in the fetus in both central and peripheral tissue from early fetal development ${ }^{55}$. Whilst entraining circadian rhythmicity may be a necessity in the non-human species for evolutionary purposes, which is to inform photoperiodic seasonal information, the role and purpose of the transplacental availability of melatonin in human is more elusive. However, melatonin is capable of reversing the rhythmic expression of the fetal clock genes in response to maternal exposure to constant light $^{56}$ and that from 33 weeks onwards, the fetus is capable of 24-hours rhythms in temperature and oxygen ${ }^{57}$. This complex prenatal interaction suggests the possibility of melatonin in developmental programming with respect to the fetal immune system. The maturation of the fetal immune system starts around 9 weeks, a period with extreme plasticity for epigenetic modification ${ }^{58}$ which makes the notion of melatonin as a programmer of fetal circadian rhythmicity, biologically plausible ${ }^{59}$.

Conversely, the anti-inflammatory facet of melatonin can act as an anti-inflammatory agent, to inhibit the immune response ${ }^{60}$ by dampening the exacerbated production of pro-inflammatory mediators, mainly cytokines, in a large number of in vivo models of inflammation ${ }^{61}$. Melatonin 
can be synthesized by lymphocytes, which help to stimulate IL-2 production in an autocrine and/or paracrine matter ${ }^{62}$. Also, melatonin can stimulate the induction of Th2 lymphocytes that produce IL-4, thereby inhibiting the function of Th1 cells ${ }^{40}$. Through the modulation in T-cell responses, melatonin exerts potential beneficial effects in suppressing various diseases with inflammatory origin, including preterm labor, gestational diabetes and preeclampsia ${ }^{63}$. The possible mechanisms of melatonin in reproductive processes is outlined in Figure 2.

\section{Circadian regulation of immunity involved in pregnancy complications through melatonin?}

The hypothalamic-pituitary axis is under circadian control and affects the timing of ovulation and hormone secretion. Deregulating circadian rhythms by inappropriate light exposure or manipulating the body clock at a molecular level negatively affects implantation and pregnancy success in animals ${ }^{64}$. Work from our group and others have shown that disruption of the circadian clock through shift work can result in the increase in infertility, menstrual dysregulation and miscarriage ${ }^{65,66}$. In chronobiology, the relationship between the circadian clock system and the immune system is previously outlined. The mediators of immune factors and circadian control are summarized in Table 2.

\section{Animal Study}

In pregnant rats, decidualization initially takes place in the antimesometrial endometrium, which later transforms into the decidua basalis persisting throughout gestation. This location of implantation and pregnancy development coincides with the melatonin binding sites, which are reported to be progressively reduced and confined to the antimesometrial non-decidualized outer stroma during pregnancy ${ }^{67}$. The decidua basalis mediates inflammatory signals that activate parturition primarily by controlling the type and function of its resident immune cells, such as the differentiation and attraction of M2 macrophages, monocytes ${ }^{68,69}$, angiogenic neutrophils ${ }^{70}$ and NK cells ${ }^{71,72}$. At term, decidual leukocytes possess increasingly inflammatory phenotype ${ }^{73}$, including increased expression of TNF- $\alpha$ and IL- 6 and reduced expression of immunoregulatory cytokines, such as IL-4 and the IL-1 receptor antagonist ${ }^{74}$. Consequently, this promote activated leukocytes within the decidua to produce more prostaglandins, which would promote uterine contractions for labor.

The ability of melatonin to promote embryo development in different species has been reported. When mouse embryos were cultured in a medium containing melatonin, increased blastocyst development rates were observed ${ }^{75}$. In another experiment using pregnant rats, suppression of maternal plasma melatonin circadian rhythm was induced by continuous light exposure during the second half of gestation. It showed several effects on fetal development ${ }^{76}$. First, it induced intrauterine growth retardation. Second, in the fetal adrenal in vivo, it markedly affected mRNA expression level of clock genes and clock-controlled genes in lowering the content and precluded the rhythm of corticosterone. Thirdly, an altered in vitro fetal adrenal response to ACTH for corticosterone production was observed. In addition, this alteration was concurrent with the relative expression changes in clock genes and steroidogenic genes. Moreover, all these changes were reversed when the mother received daily dosage of melatonin during the subjective night, which is at the endogenous circadian rhythm during nighttime.

\section{$\underline{\text { Human Study }}$}


Dysregulation of immune responses is detrimental to early pregnancy and obstetrics outcomes such as recurrent pregnancy loss, implantation failure, preeclampsia, preterm birth and intrauterine growth restriction ${ }^{77,78}$. The question of which specific conditions of reproductive failure is directly attributable to a deranged immune system in conjunction with a disrupted circadian clock is not yet fully known and in many cases, can only be a biological plausible extrapolation. The proposed association between the circadian clock (central and peripheral), the clock-controlled immune related factors and pregnancy-related pathologies are illustrated in Figure 3. Transcriptomic analysis of the uterine pre-receptive to receptive phase in the human endometrium study utilising the more precise method of RNA-Seq has identified novel transcripts, with gene ontology and pathway analysis highlighting 'circadian rhythm' as one the most significantly up-regulated pathways involved with metabolism and mineral absorption ${ }^{79}$. Muter et al., 2015 showed that the siRNA knock down of Per2 in endometrial culture does lead to a grossly disorganized decidual response and differentially expressed transcripts, and hypothesized that disordered pro-inflammatory decidual response prolongs the window of endometrial receptivity, which in turn increases the risk for out-of-phase implantation and recurrent pregnancy loss ${ }^{80}$.

The canonical clock genes are described in distinct zones within the term placenta but the circadian changes were found not to be robust nor well-coordinated ${ }^{4}$. The state of pregnancy leads to maternal 'adaptations' in the increased expression of Per2 in the SCN, Per3 in the maternal liver, but dampens those of Clock, Bmal1, Per1, Cry1 and Cry2 ${ }^{4}$. It is plausible that the chronobiologically sensitive mediator - melatonin completes the linkage between the maternal, foetal and placental physiological rhythms, through mechanisms of entrainment and direct biological actions. The benefits of melatonin may extend from implantation period ${ }^{81}$ to later in gestation, where the elevated levels associated with the $3^{\text {rd }}$ trimester of pregnancy, improves progesterone synthesis, inhibits premature release of oxytocin until the time of parturition ${ }^{82}$.

The paradox of the immunologically privileged fetus may in fact be one intended by nature where the maternal immune system intents to recognize, and even nurture, the developing trophoblast. Melatonin innate rhythm correlates with rhythmicity in the Th1/Th2 ratio in maintaining the survival of the fetus ${ }^{83}$. Increased IL-12 expression (Th1) and lowered IL-10 expression (Th2) in women is associated with an increased risk of preterm birth ${ }^{84}$. However, it has become increasingly clear that melatonin also acts on T-lymphocyte precursors and affects both NK cell and monocyte function. Several studies found that peripheral NK cells are increased in women with recurrent miscarriages ${ }^{85,86}$. And during luteal phase and early gestation in the uterus, the uterine NK (UNK) cells are the major lymphocyte population present within the endometrium $^{87}$. While the specific functions of these cells remain unknown, they appear to play a role in the implantation process and development of the placenta ${ }^{88}$. When comparing between NK cells in our circulation with those found in the uterine endometrium, uNK cells are $\mathrm{CD} 56^{\text {high }} \mathrm{CD} 16^{-}$in receptivity and lower NK activity, whereas typical NK cells are $\mathrm{CD} 56^{\mathrm{dim}} \mathrm{CD} 16^{+}$in receptivity and higher NK activity ${ }^{89}$. In addition, unlike the typical NK cells found in the circulation, they are not phagocytotic and do not lyse the trophoblast. Instead, they produce numerous cytokines that promote trophoblast growth and proliferation in vitro ${ }^{90}$. The presence of NK cells at the maternal-fetal interface during implantation in many species suggests that trophoblasts are target cells for uNK cells ${ }^{91}$. Hence, it is logical that uNK cells play a role in the dynamic changes of the human endometrial epithelium that occurs throughout the menstrual cycle and early pregnancy. However, the exact mechanistic relationship between these nonphagocytotic uNK cells and the circadian clock remains to be uncovered. 
VEGF (vascular endothelial growth factor), a key player in pathological reproductive processes such as preeclampsia, is known to be controlled by the complex CLOCK-BMAL pathway. Cell culture experiments showed that the transcription of VEGF co-transfected with CLOCK-BMAL increases the level of VEGF protein ${ }^{92}$ and the transient expression of Per2 and Cry1 would inhibit such protein expression. In the human cancer xenograft model, the excised lesion showed circadian rhythmic expressions of Clock genes and VEGF. VEGF and BMAL1 have similar peaked expression during the light cycle. Melatonin has been reported to inhibit the expression of VEGF and hypoxia-induced factor- $1 \alpha$ (HIF-1 $\alpha$ ), a mediator of VEGF ${ }^{93}$. Also, BMAL1 has been shown to dimerize with HIF-1 $\alpha$ in vitro and potentially bind to hypoxia response elements in gene promoters and drive the transcription of target genes ${ }^{94}$. However, it remains controversial whether BMAL1/HIF-1 $\alpha$ dimer can induce VEGF transcription in vivo. The hypothesis that VEGF detrimentally influences the outcome of preeclampsia under the influence of clock genes network is entirely speculative. Normal blood pressure is known to vary in a circadian manner, but in those with preeclampsia, this circadian relationship is lost. As VEGF is predominantly active within the vascular endothelial cells, it lends itself as a prime candidate to this speculative, but plausible association of a 'clock' determining factor for preeclampsia. If the jig-saw pieces relating to melatonin rhythms ${ }^{95}$, poor reproductive outcomes $^{96}$, aberrant expression and activity of VEGF in the fetal-placenta unit ${ }^{97}$ and an altered circadian rhythm ${ }^{98}$ were better assembled with the support of data from well-planned prospective research studies, there is likely to be a new and promising paradigm shift in terms of diagnostics and therapeutics.

Although melatonin seemed indispensable and beneficial during pregnancy and early fetal development, there is currently no evidence from randomized-controlled trial that treatment with melatonin given to the mother during pregnancy has any beneficial effect on the fetal growth. Thus, the effect of exogenous melatonin on immunity during pregnancy remains to be elucidated.

\section{Conclusion}

In summary, both regular circadian rhythms and cyclic melatonin availability are critical in assuring optimal immune regulation during pregnancy. Without a doubt, the effect of melatonin in rhythmic variations on gene expression suggests an important role in uterine receptivity and its support for fetal growth and development. It seems likely that a desynchronization of this system could contribute to possible consequences of impaired implantation, fetal development and beyond. Introduction of exogenous melatonin might have multiple beneficial effects on protecting the mother and fetus toward immunocompromised pregnancy. However, much work is still needed to ascertain the therapeutic effect of melatonin to modulate circadian influences on immune response during pregnancy. 


\section{Acknowledgement}

This paper is partly funded by a grant from the Hong Kong Obstetrical \& Gynaecological Trust Fund 2016-2017 to GCWM, XYC, JZW, CCW and TCL. 


\section{References}

$1 \quad$ Medawar PB: Immunity to homologous grafted skin; the fate of skin homografts transplanted to the brain, to subcutaneous tissue, and to the anterior chamber of the eye. Br J Exp Pathol 1948;29:58-69.

2 Medawar PB: Some immunological and endocrinological problems raised by the evolution of viviparity in vertebrates. Symp Soc Exp Biol 1952;7:320-338.

3 Murphy VE, Smith R, Giles WB, Clifton VL: Endocrine regulation of human fetal growth: the role of the mother, placenta, and fetus. Endocr Rev 2006;27:141-169.

4 Waddell BJ, Wharfe MD, Crew RC, Mark PJ: A rhythmic placenta? Circadian variation, clock genes and placental function. Placenta 2012;33:533-539.

5 Dijk DJ, Duffy JF: Circadian regulation of human sleep and age-related changes in its timing, consolidation and EEG characteristics. Ann Med 1999;31:130-140.

6 Van Someren EJ: Circadian rhythms and sleep in human aging. Chronobiol Int 2000;17:233-243.

7 Copinschi G, Van Cauter E: Effects of ageing on modulation of hormonal secretions by sleep and circadian rhythmicity. Horm Res 1995;43:20-24.

8 Janich P, Meng QJ, Benitah SA: Circadian control of tissue homeostasis and adult stem cells. Curr Opin Cell Biol 2014;31:8-15.

9 Cooke-Ariel $\mathrm{H}$ : Circadian variations in cardiovascular function and their relation to the occurrence and timing of cardiac events. Am J Health Syst Pharm 1998;55 Suppl 3:S5-11.

10 Shackelford PG, Feigin RD: Periodicity of susceptibility to pneumococcal infection: influence of light and adrenocortical secretions. Science 1973;182:285-287.

11 Halberg F, Johnson EA, Brown BW, Bittner JJ: Susceptibility rhythm to E. coli endotoxin and bioassay. Proc Soc Exp Biol Med 1960;103:142-144.

12 Dibner $\mathrm{C}$, Schibler U, Albrecht U: The mammalian circadian timing system: organization and coordination of central and peripheral clocks. Annu Rev Physiol 2010;72:517-549.

13 Dunlap JC: Molecular bases for circadian clocks. Cell 1999;96:271-290.

14 Hardin PE, Yu W: Circadian transcription: passing the HAT to CLOCK. Cell 2006;125:424426.

15 Valenzuela FJ, Torres-Farfan C, Richter HG, Mendez N, Campino C, Torrealba F, Valenzuela GJ, Seron-Ferre M: Clock gene expression in adult primate suprachiasmatic nuclei and adrenal: is the adrenal a peripheral clock responsive to melatonin? Endocrinology 2008;149:1454-1461.

16 Richards J, Gumz ML: Advances in understanding the peripheral circadian clocks. FASEB J 2012;26:3602-3613.

17 Edgar RS, Green EW, Zhao Y, van Ooijen G, Olmedo M, Qin X, Xu Y, Pan M, Valekunja UK, Feeney KA, Maywood ES, Hastings MH, Baliga NS, Merrow M, Millar AJ, Johnson CH, Kyriacou CP, O'Neill JS, Reddy AB: Peroxiredoxins are conserved markers of circadian rhythms. Nature 2012;485:459-464.

18 Man K, Loudon A, Chawla A: Immunity around the clock. Science 2016;354:999-1003.

19 Ivashkiv LB: Epigenetic regulation of macrophage polarization and function. Trends Immunol 2013;34:216-223.

20 Silver AC, Arjona A, Walker WE, Fikrig E: The circadian clock controls toll-like receptor 9mediated innate and adaptive immunity. Immunity 2012;36:251-261.

21 Brzezinski A, Seibel MM, Lynch HJ, Deng MH, Wurtman RJ: Melatonin in human preovulatory follicular fluid. J Clin Endocrinol Metab 1987;64:865-867. 
Okatani Y, Okamoto K, Hayashi K, Wakatsuki A, Tamura S, Sagara Y: Maternal-fetal transfer of melatonin in pregnant women near term. J Pineal Res 1998;25:129-134. Nakao A: Temporal regulation of cytokines by the circadian clock. J Immunol Res 2014;2014:614529.

24 Logan RW, Sarkar DK: Circadian nature of immune function. Mol Cell Endocrinol 2012;349:82-90.

Cermakian N, Lange T, Golombek D, Sarkar D, Nakao A, Shibata S, Mazzoccoli G: Crosstalk between the circadian clock circuitry and the immune system. Chronobiol Int 2013;30:870-888.

26 Feigin RD, Dangerfield HG, Beisel WR: Circadian periodicity of blood amino acids in normal and adrenalectomized mice. Nature 1969;221:94-95.

27 Scheiermann C, Kunisaki Y, Lucas D, Chow A, Jang JE, Zhang D, Hashimoto D, Merad M, Frenette PS: Adrenergic nerves govern circadian leukocyte recruitment to tissues. Immunity 2012;37:290-301.

28 Nguyen KD, Fentress SJ, Qiu Y, Yun K, Cox JS, Chawla A: Circadian gene Bmal1 regulates diurnal oscillations of Ly6C(hi) inflammatory monocytes. Science 2013;341:1483-1488.

29 Keller M, Mazuch J, Abraham U, Eom GD, Herzog ED, Volk HD, Kramer A, Maier B: A circadian clock in macrophages controls inflammatory immune responses. Proc Natl Acad Sci U S A 2009;106:21407-21412.

30 Wang T, Wang Z, Yang P, Xia L, Zhou M, Wang S, Du J, Zhang J: PER1 prevents excessive innate immune response during endotoxin-induced liver injury through regulation of macrophage recruitment in mice. Cell Death Dis 2016;7:e2176.

31 Narasimamurthy R, Hatori M, Nayak SK, Liu F, Panda S, Verma IM: Circadian clock protein cryptochrome regulates the expression of proinflammatory cytokines. Proc Natl Acad Sci U S A 2012;109:12662-12667.

32 Spengler ML, Kuropatwinski KK, Comas M, Gasparian AV, Fedtsova N, Gleiberman AS, Gitlin, II, Artemicheva NM, Deluca KA, Gudkov AV, Antoch MP: Core circadian protein CLOCK is a positive regulator of NF-kappaB-mediated transcription. Proc Natl Acad Sci U S A 2012;109:E2457-2465.

33 Gibbs JE, Blaikley J, Beesley S, Matthews L, Simpson KD, Boyce SH, Farrow SN, Else KJ, Singh D, Ray DW, Loudon AS: The nuclear receptor REV-ERBalpha mediates circadian regulation of innate immunity through selective regulation of inflammatory cytokines. Proc Natl Acad Sci U S A 2012;109:582-587.

34 Mendez-Ferrer S, Lucas D, Battista M, Frenette PS: Haematopoietic stem cell release is regulated by circadian oscillations. Nature 2008;452:442-447.

35 Wilson EH, Weninger W, Hunter CA: Trafficking of immune cells in the central nervous system. J Clin Invest 2010;120:1368-1379.

36 Hardeland R, Pandi-Perumal SR, Cardinali DP: Melatonin. Int J Biochem Cell Biol 2006;38:313-316.

37 Cutler WB, Garcia CR: The psychoneuroendocrinology of the ovulatory cycle of woman: a review. Psychoneuroendocrinology 1980;5:89-111.

38 Brzezinski A: Melatonin in humans. N Engl J Med 1997;336:186-195.

39 Dubocovich ML, Delagrange P, Krause DN, Sugden D, Cardinali DP, Olcese J: International Union of Basic and Clinical Pharmacology. LXXV. Nomenclature, classification, and pharmacology of G protein-coupled melatonin receptors. Pharmacol Rev 2010;62:343-380.

40 Szczepanik M: Melatonin and its influence on immune system. J Physiol Pharmacol 2007;58 Suppl 6:115-124. 
41 Venegas C, Garcia JA, Escames G, Ortiz F, Lopez A, Doerrier C, Garcia-Corzo L, Lopez LC, Reiter RJ, Acuna-Castroviejo D: Extrapineal melatonin: analysis of its subcellular distribution and daily fluctuations. J Pineal Res 2012;52:217-227.

42 Christ E, Pfeffer M, Korf HW, von Gall C: Pineal melatonin synthesis is altered in Period1 deficient mice. Neuroscience 2010;171:398-406.

43 Pfeffer M, Rauch A, Korf HW, von Gall C: The endogenous melatonin (MT) signal facilitates reentrainment of the circadian system to light-induced phase advances by acting upon MT2 receptors. Chronobiol Int 2012;29:415-429.

44 Maestroni GJ, Covacci V, Conti A: Hematopoietic rescue via T-cell-dependent, endogenous granulocyte-macrophage colony-stimulating factor induced by the pineal neurohormone melatonin in tumor-bearing mice. Cancer Res 1994;54:2429-2432.

45 Miller SC, Pandi-Perumal SR, Esquifino Al, Cardinali DP, Maestroni GJ: The role of melatonin in immuno-enhancement: potential application in cancer. Int J Exp Pathol 2006;87:81-87.

$46 \quad$ Kuhlwein E, Irwin M: Melatonin modulation of lymphocyte proliferation and Th1/Th2 cytokine expression. J Neuroimmunol 2001;117:51-57.

47 Paredes SD, Sanchez S, Parvez H, Rodriguez AB, Barriga C: Altered circadian rhythms of corticosterone, melatonin, and phagocytic activity in response to stress in rats. Neuro Endocrinol Lett 2007;28:489-495.

48 Alvarez-Garcia V, Gonzalez A, Alonso-Gonzalez C, Martinez-Campa C, Cos S: Melatonin interferes in the desmoplastic reaction in breast cancer by regulating cytokine production. J Pineal Res 2012;52:282-290.

49 Kaur C, Ling EA: Effects of melatonin on macrophages/microglia in postnatal rat brain. $J$ Pineal Res 1999;26:158-168.

50 Currier NL, Sun LZ, Miller SC: Exogenous melatonin: quantitative enhancement in vivo of cells mediating non-specific immunity. J Neuroimmunol 2000;104:101-108.

51 Lissoni P, Marelli O, Mauri R, Resentini M, Franco P, Esposti D, Esposti G, Fraschini F, Halberg F, Sothern RB, et al.: Ultradian chronomodulation by melatonin of a Placebo effect upon human killer cell activity. Chronobiologia 1986;13:339-343.

52 Ren W, Liu G, Chen S, Yin J, Wang J, Tan B, Wu G, Bazer FW, Peng Y, Li T, Reiter RJ, Yin Y: Melatonin signaling in T cells: Functions and applications. J Pineal Res 2017.

53 Carrillo-Vico A, Lardone PJ, Fernandez-Santos JM, Martin-Lacave I, Calvo JR, Karasek M, Guerrero JM: Human lymphocyte-synthesized melatonin is involved in the regulation of the interleukin-2/interleukin-2 receptor system. J Clin Endocrinol Metab 2005;90:9921000.

54 Kivela A: Serum melatonin during human pregnancy. Acta Endocrinol (Copenh) 1991;124:233-237.

55 Thomas L, Drew JE, Abramovich DR, Williams LM: The role of melatonin in the human fetus (review). Int J Mol Med 1998;1:539-543.

56 Cisternas CD, Compagnucci MV, Conti NR, Ponce RH, Vermouth NT: Protective effect of maternal prenatal melatonin administration on rat pups born to mothers submitted to constant light during gestation. Braz J Med Biol Res 2010;43:874-882.

57 Bauer J, Janecke A, Gerss J, Masjosthusmann K, Werner C, Hoffmann G: Circadian variation on oxygen consumption in preterm infants. J Perinat Med 2009;37:413-417. Chen T, Liu HX, Yan HY, Wu DM, Ping J: Developmental origins of inflammatory and immune diseases. Mol Hum Reprod 2016;22:858-865.

59 Chen YC, Sheen JM, Tiao MM, Tain YL, Huang LT: Roles of melatonin in fetal programming in compromised pregnancies. Int J Mol Sci 2013;14:5380-5401. 
Esposito E, Cuzzocrea S: Antiinflammatory activity of melatonin in central nervous system. Curr Neuropharmacol 2010;8:228-242.

61 Mei Q, Yu JP, Xu JM, Wei W, Xiang L, Yue L: Melatonin reduces colon immunological injury in rats by regulating activity of macrophages. Acta Pharmacol Sin 2002;23:882886.

62 Carrillo-Vico A, Calvo JR, Abreu P, Lardone PJ, Garcia-Maurino S, Reiter RJ, Guerrero JM: Evidence of melatonin synthesis by human lymphocytes and its physiological significance: possible role as intracrine, autocrine, and/or paracrine substance. FASEB J 2004;18:537-539.

63 Agarwal A, Gupta S, Sharma RK: Role of oxidative stress in female reproduction. Reprod Biol Endocrinol 2005;3:28.

64 Summa KC, Vitaterna MH, Turek FW: Environmental perturbation of the circadian clock disrupts pregnancy in the mouse. PLoS One 2012;7:e37668.

65 Stocker LJ, Macklon NS, Cheong YC, Bewley SJ: Influence of shift work on early reproductive outcomes: a systematic review and meta-analysis. Obstet Gynecol 2014;124:99-110.

Fernandez RC, Marino JL, Varcoe TJ, Davis S, Moran LJ, Rumbold AR, Brown HM, Whitrow MJ, Davies MJ, Moore VM: Fixed or Rotating Night Shift Work Undertaken by Women: Implications for Fertility and Miscarriage. Semin Reprod Med 2016;34:74-82. Zhao H, Pang SF, Poon AM: Variations of $\mathrm{mt} 1$ melatonin receptor density in the rat uterus during decidualization, the estrous cycle and in response to exogenous steroid treatment. J Pineal Res 2002;33:140-145.

68 Qin B, Deng Y: Overexpression of circadian clock protein cryptochrome (CRY) 1 alleviates sleep deprivation-induced vascular inflammation in a mouse model. Immunol Lett 2015;163:76-83.

69 Gagnidze K, Hajdarovic KH, Moskalenko M, Karatsoreos IN, McEwen BS, Bulloch K: Nuclear receptor REV-ERBalpha mediates circadian sensitivity to mortality in murine vesicular stomatitis virus-induced encephalitis. Proc Natl Acad Sci U S A 2016;113:57305735.

70 Ella K, Csepanyi-Komi R, Kaldi K: Circadian regulation of human peripheral neutrophils. Brain Behav Immun 2016;57:209-221.

71 Logan RW, Wynne O, Levitt D, Price D, Sarkar DK: Altered circadian expression of cytokines and cytolytic factors in splenic natural killer cells of Per1(-/-) mutant mice. J Interferon Cytokine Res 2013;33:108-114.

72 Liu J, Malkani G, Shi X, Meyer M, Cunningham-Runddles S, Ma X, Sun ZS: The circadian clock Period 2 gene regulates gamma interferon production of NK cells in host response to lipopolysaccharide-induced endotoxic shock. Infect Immun 2006;74:4750-4756. Galazka K, Wicherek L, Pitynski K, Kijowski J, Zajac K, Bednarek W, Dutsch-Wicherek M, Rytlewski K, Kalinka J, Basta A, Majka M: Changes in the subpopulation of CD25+ CD4+ and FOXP3+ regulatory $T$ cells in decidua with respect to the progression of labor at term and the lack of analogical changes in the subpopulation of suppressive B7-H4 macrophages--a preliminary report. Am J Reprod Immunol 2009;61:136-146.

74 Castillo-Castrejon M, Meraz-Cruz N, Gomez-Lopez N, Flores-Pliego A, Beltran-Montoya J, Viveros-Alcaraz M, Vadillo-Ortega F: Choriodecidual cells from term human pregnancies show distinctive functional properties related to the induction of labor. Am J Reprod Immunol 2014;71:86-93.

75 Ishizuka B, Kuribayashi Y, Murai K, Amemiya A, Itoh MT: The effect of melatonin on in vitro fertilization and embryo development in mice. J Pineal Res 2000;28:48-51. 
Mendez N, Abarzua-Catalan L, Vilches N, Galdames HA, Spichiger C, Richter HG, Valenzuela GJ, Seron-Ferre M, Torres-Farfan C: Timed maternal melatonin treatment reverses circadian disruption of the fetal adrenal clock imposed by exposure to constant light. PLoS One 2012;7:e42713.

77 Kwak-Kim J, Bao S, Lee SK, Kim JW, Gilman-Sachs A: Immunological modes of pregnancy loss: inflammation, immune effectors, and stress. Am J Reprod Immunol 2014;72:129140.

78 Szekeres-Bartho J: Immunological relationship between the mother and the fetus. Int Rev Immunol 2002;21:471-495.

79 Hu S, Yao G, Wang Y, Xu H, Ji X, He Y, Zhu Q, Chen Z, Sun Y: Transcriptomic changes during the pre-receptive to receptive transition in human endometrium detected by RNA-Seq. J Clin Endocrinol Metab 2014;99:E2744-2753.

80 Muter J, Lucas ES, Chan YW, Brighton PJ, Moore JD, Lacey L, Quenby S, Lam EW, Brosens $\mathrm{JJ}$ : The clock protein period 2 synchronizes mitotic expansion and decidual transformation of human endometrial stromal cells. FASEB J 2015;29:1603-1614.

81 Tenorio F, Simoes Mde J, Teixeira VW, Teixeira AA: Effects of melatonin and prolactin in reproduction: review of literature. Rev Assoc Med Bras (1992) 2015;61:269-274.

82 Reiter RJ, Tan DX, Manchester LC, Paredes SD, Mayo JC, Sainz RM: Melatonin and reproduction revisited. Biol Reprod 2009;81:445-456.

83 Saito S: Cytokine network at the feto-maternal interface. J Reprod Immunol 2000;47:87103.

84 Szereday L, Varga P, Szekeres-Bartho J: Cytokine production by lymphocytes in pregnancy. Am J Reprod Immunol 1997;38:418-422.

85 Michou VI, Kanavaros P, Athanassiou V, Chronis GB, Stabamas S, Tsilivakos V: Fraction of the peripheral blood concentration of CD56+/CD16-/CD3- cells in total natural killer cells as an indication of fertility and infertility. Fertil Steril 2003;80 Suppl 2:691-697.

86 Yamada H, Morikawa M, Furuta I, Kato EH, Shimada S, Iwabuchi K, Minakami H: Intravenous immunoglobulin treatment in women with recurrent abortions: increased cytokine levels and reduced Th1/Th2 lymphocyte ratio in peripheral blood. Am J Reprod Immunol 2003;49:84-89.

87 Trundley A, Moffett A: Human uterine leukocytes and pregnancy. Tissue Antigens 2004;63:1-12.

88 Demir R, Kayisli UA, Celik-Ozenci C, Korgun ET, Demir-Weusten AY, Arici A: Structural differentiation of human uterine luminal and glandular epithelium during early pregnancy: an ultrastructural and immunohistochemical study. Placenta 2002;23:672684.

89 Acar N, Ustunel I, Demir R: Uterine natural killer (UNK) cells and their missions during pregnancy: a review. Acta Histochem 2011;113:82-91.

90 Tabiasco J, Rabot M, Aguerre-Girr M, El Costa H, Berrebi A, Parant O, Laskarin G, Juretic K, Bensussan A, Rukavina D, Le Bouteiller P: Human decidual NK cells: unique phenotype and functional properties -- a review. Placenta 2006;27 Suppl A:S34-39.

91 Loke YW, King A, Burrows TD: Decidua in human implantation. Hum Reprod 1995;10

Suppl 2:14-21.

92 Koyanagi S, Kuramoto Y, Nakagawa H, Aramaki H, Ohdo S, Soeda S, Shimeno H: A molecular mechanism regulating circadian expression of vascular endothelial growth factor in tumor cells. Cancer Res 2003;63:7277-7283. 

Alvarez-Garcia V, Gonzalez A, Alonso-Gonzalez C, Martinez-Campa C, Cos S: Regulation of vascular endothelial growth factor by melatonin in human breast cancer cells. J Pineal Res 2013;54:373-380.

94 Hogenesch JB, Gu YZ, Jain S, Bradfield CA: The basic-helix-loop-helix-PAS orphan MOP3 forms transcriptionally active complexes with circadian and hypoxia factors. Proc NatI Acad Sci U S A 1998;95:5474-5479.

95 Dragojevic Dikic S, Jovanovic AM, Dikic S, Jovanovic T, Jurisic A, Dobrosavljevic A: Melatonin: a "Higgs boson" in human reproduction. Gynecol Endocrinol 2015;31:92-101.

96 Tranquilli AL, Turi A, Giannubilo SR, Garbati E: Circadian melatonin concentration rhythm is lost in pregnant women with altered blood pressure rhythm. Gynecol Endocrinol 2004;18:124-129.

97 Fan X, Rai A, Kambham N, Sung JF, Singh N, Petitt M, Dhal S, Agrawal R, Sutton RE, Druzin ML, Gambhir SS, Ambati BK, Cross JC, Nayak NR: Endometrial VEGF induces placental sFLT1 and leads to pregnancy complications. J Clin Invest 2014;124:4941-4952. 98 Croteau A, Marcoux S, Brisson C: Work activity in pregnancy, preventive measures, and the risk of delivering a small-for-gestational-age infant. Am J Public Health 2006;96:846855.

99 Anthony RV, Pratt SL, Liang R, Holland MD: Placental-fetal hormonal interactions: impact on fetal growth. J Anim Sci 1995;73:1861-1871.

100 Faas MM, Spaans F, De Vos P: Monocytes and macrophages in pregnancy and preeclampsia. Front Immunol 2014;5:298. 
Table 1. Mediators of immune factors and circadian control.

\begin{tabular}{|c|c|c|c|c|}
\hline $\begin{array}{l}\text { Immune Cell } \\
\text { Types }\end{array}$ & $\begin{array}{l}\text { Clock- } \\
\text { controlled } \\
\text { Expression }\end{array}$ & $\begin{array}{l}\text { Growth Factors } \\
\text { and Cytokines } \\
\text { Involved }\end{array}$ & $\begin{array}{l}\text { Consequences on } \\
\text { abolishment of Clock } \\
\text { expression on immunity }\end{array}$ & References \\
\hline Neutrophil & $B M A L 1$ & CXCL12, CXCL5 & $\begin{array}{l}\text { Increase inflammatory } \\
\text { responses to } \\
\text { lipopolysaccharide and } \\
\text { bacterial infection }\end{array}$ & $\begin{array}{l}\text { (Ella K et al, } \\
2016)^{70}\end{array}$ \\
\hline Monocyte & BMAL1 & CCL2 & $\begin{array}{l}\text { Attenuates monocyte } \\
\text { recruitment and } \\
\text { inflammation }\end{array}$ & $\begin{array}{l}\text { (Gagnidze K et } \\
\text { al, 2016) }\end{array}$ \\
\hline Monocyte & CRY1 & $\begin{array}{l}\text { IL-1 } 1 \beta, \text { IL- } 6 \text { and } \\
\text { TNF- } \alpha\end{array}$ & Increase in inflammation & $\begin{array}{l}\text { (Qin B et al, } \\
\text { 2015) }\end{array}$ \\
\hline $\begin{array}{l}\text { Natural Killer } \\
\text { cells }\end{array}$ & Per1 & $\begin{array}{l}\text { interferon- }- \text {, } \\
\text { perforin and } \\
\text { granzyme B }\end{array}$ & $\begin{array}{l}\text { Altered rhythms of NK } \\
\text { cell immune factors }\end{array}$ & $\begin{array}{l}\text { (Logan RW et } \\
\text { al, 2013) }\end{array}$ \\
\hline $\begin{array}{l}\text { Natural Killer } \\
\text { cells }\end{array}$ & Per2 & $\begin{array}{l}\text { IFN-gamma and } \\
\text { IL-1 } \beta\end{array}$ & Decrease NK cell function & $\begin{array}{l}\text { (Liu J et al, } \\
2006)^{72}\end{array}$ \\
\hline Macrophage & CRY1 & $\begin{array}{l}\text { TNF- } \alpha, \text { IL-6, } \\
\text { and MIP-1 } \alpha\end{array}$ & $\begin{array}{l}\text { Increase expression of } \\
\text { Inflammatory cytokines }\end{array}$ & $\begin{array}{c}\text { (Keller M et al, } \\
2009)^{29}\end{array}$ \\
\hline
\end{tabular}


Table 2. Mediators of immune factors and circadian control in reproduction.

\begin{tabular}{|c|c|c|c|c|}
\hline $\begin{array}{l}\text { Immune } \\
\text { Factors }\end{array}$ & $\begin{array}{l}\text { Clock- } \\
\text { controlled } \\
\text { or } \\
\text { Associated } \\
\text { Genes } \\
\text { Involved }\end{array}$ & $\begin{array}{c}\text { Role in Reproductive } \\
\text { processes }\end{array}$ & $\begin{array}{l}\text { Pathological } \\
\text { processes } \\
\text { related }\end{array}$ & References \\
\hline \multicolumn{5}{|c|}{ Cytokines and Recognition Receptors } \\
\hline 个TLRs & 个BMAL1 & $\begin{array}{l}\text { Influence immune cell } \\
\text { recruitment, cytokine } \\
\text { secretion and decidual } \\
\text { response to invading } \\
\text { pathogens }\end{array}$ & $\begin{array}{l}\text { Preeclampsia, } \\
\text { intrauterine } \\
\text { growth } \\
\text { restriction, and } \\
\text { preterm labor }\end{array}$ & $\begin{array}{l}\text { (Silver AC et al, } \\
2012)^{20}\end{array}$ \\
\hline $\begin{array}{l}\downarrow \text { TNF- } \alpha \text { and } \\
\qquad \text { IL-6 }\end{array}$ & 个Per2 & $\begin{array}{l}\text { Decrease inflammatory } \\
\text { response }\end{array}$ & Preterm Birth & $\begin{array}{l}\text { (Castillo-Castrejon } \\
\text { M et al. 2014) }\end{array}$ \\
\hline 个 IL-4 & 个Per2 & $\begin{array}{c}\text { Reduce uterine } \\
\text { contraction during } \\
\text { early gestation }\end{array}$ & Preterm Birth & $\begin{array}{l}\text { (Castillo-Castrejon } \\
\text { M et al. 2014) }\end{array}$ \\
\hline$\downarrow N F-k B$ & $\begin{array}{c}\downarrow \text { Cry1, } \\
\text { Cry2 }\end{array}$ & $\begin{array}{l}\text { Decrease inflammatory } \\
\text { response }\end{array}$ & Preterm Birth & $\begin{array}{c}\text { (Narasimamurthy R } \\
\text { et al, 2012) }\end{array}$ \\
\hline$\uparrow \mathrm{IL}-10$ & 个Per2 & $\begin{array}{l}\text { Anti-inflammatory } \\
\text { response }\end{array}$ & Preterm Birth & $\begin{array}{l}\text { (Castillo-Castrejon } \\
\text { M et al. 2014) }\end{array}$ \\
\hline \multicolumn{5}{|c|}{ Remodeling Factors } \\
\hline VEGF & $\begin{array}{l}\text { CLOCK, } \\
\text { BMAL1 }\end{array}$ & $\begin{array}{c}\text { Stimulation } \\
\text { monocyte/macrophage } \\
\text { migration }\end{array}$ & Preeclampsia & $\begin{array}{c}\text { (Anthony RV et al, } \\
1995)^{99}\end{array}$ \\
\hline \multicolumn{5}{|l|}{ Immune Cells } \\
\hline 个Macrophage & $\begin{array}{l}\text { 个Per2, } \\
B M A L 1\end{array}$ & $\begin{array}{l}\text { Vascular remodeling } \\
\text { and clearance of } \\
\text { apoptotic cells }\end{array}$ & Preeclampsia & $\begin{array}{l}\text { (Faas M et al, } \\
2014)^{100}\end{array}$ \\
\hline $\begin{array}{l}\text { Tregulatory } \\
\text { cells }\end{array}$ & 个BMAL1 & Shift Th1 to Th2 & Preterm birth & $\begin{array}{l}\text { (Yamada H et al, } \\
\text { 2003) }\end{array}$ \\
\hline
\end{tabular}

A summary of mediators known involved in immunity during pregnancy and their corresponding Clock gene control.

$\uparrow$, increase activity; $\downarrow$, decrease activity; TLRs, toll-like receptors; TGF- $\alpha$, Transforming Growth Factor$\alpha$; IL-6, interleukin-6; IL-4, interleukin-4; NF-KB, nuclear factor kappa-light-chain-enhancer of activated B cells, IL-10, interleukin-10; TH1/2: helper T1/helper T2. 


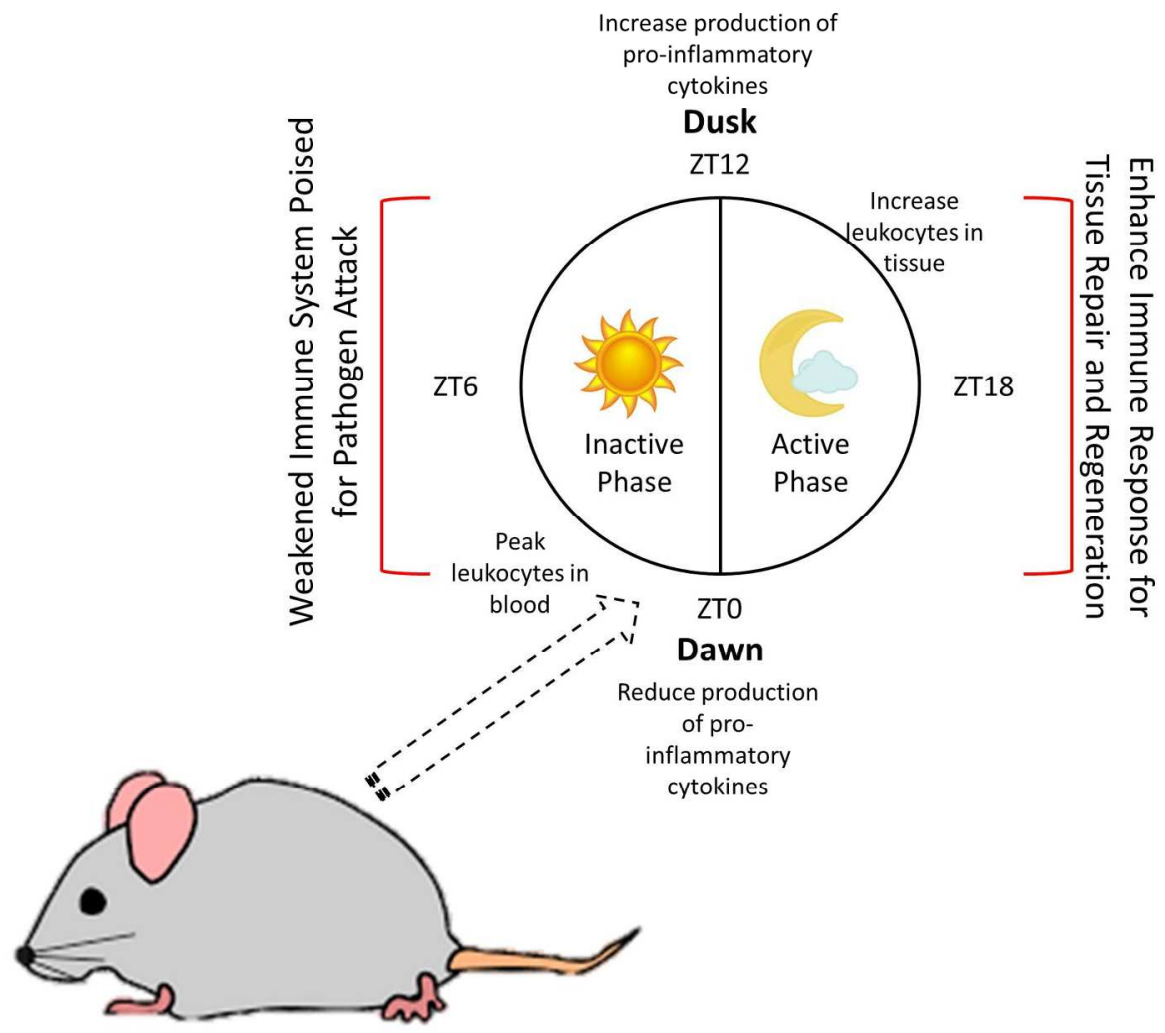

Figure 1. Illustration on circadian effects on immune function in mammal.

In using a mouse model, the changes in leukocytes infiltration to the tissue is maintained in a circadian cycle. As mice are nocturnal animal, they are most active during nighttime (ZT12-ZTO), whereas the immune cells are most active for tissue repair and regeneration. While in human, the active phase would shifted to being in the daytime (ZTO-ZT12), for which the immune cells response are enhanced for tissue repair and regeneration.

ZT: Zeitgeber time

Figure 1. Illustration on circadian effects on immune function in mammal.

$351 \times 365 \mathrm{~mm}(150 \times 150 \mathrm{DPI})$ 


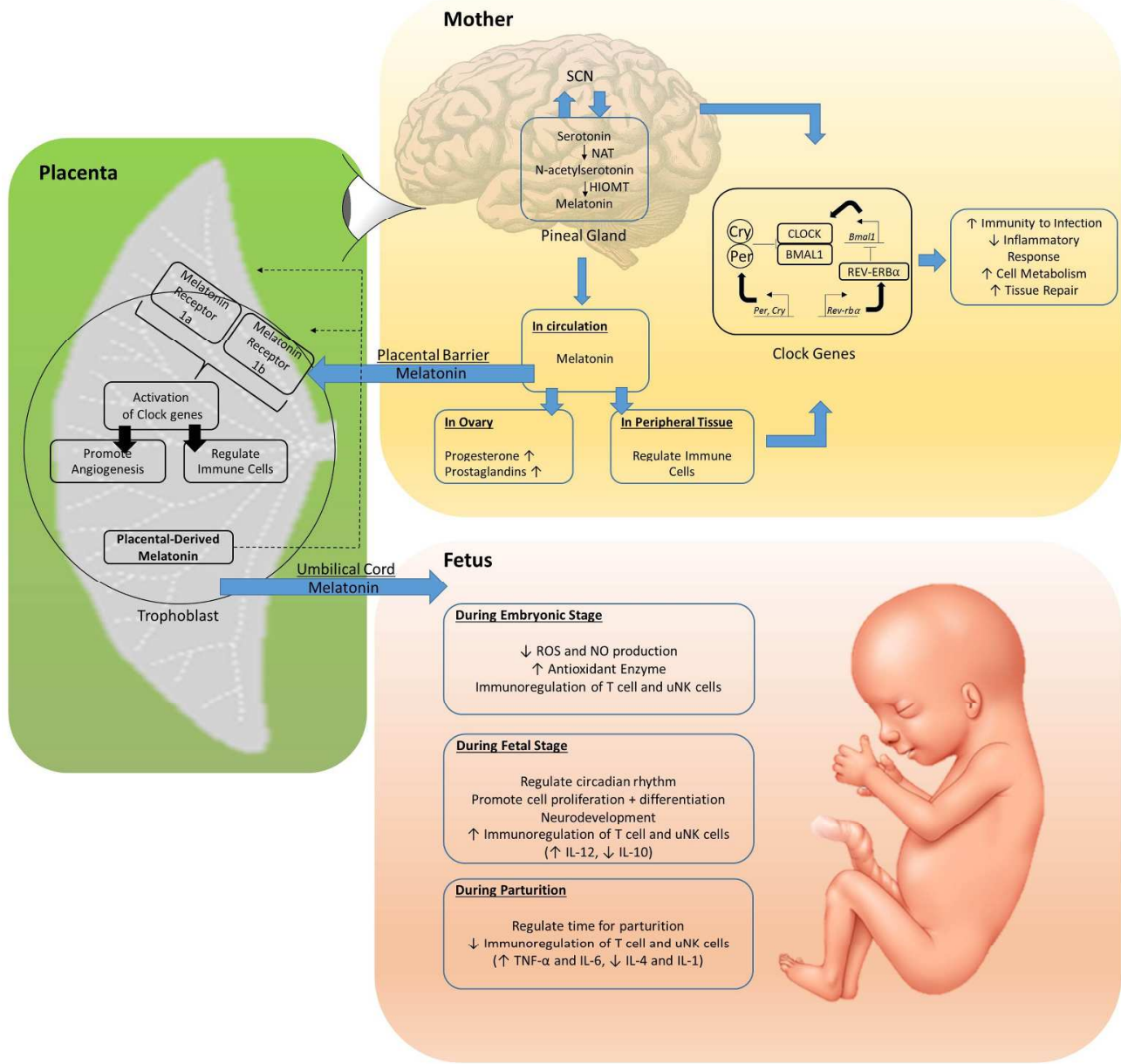

Figure 2. Schematic Diagram of Melatonin on Circadian Cycle During Pregnancy.

$\uparrow$, increase activity; $\downarrow$, decrease activity; NAT, N-acetyltransferase; HIOMT, N-Acetylserotonin O-methyltransferase; ROS, reactive oxygen species; NO, nitric oxide; IL-12, interleukin-12; IL-10, interleukin-10; IL-4, interleukin-4; IL-1, interleukin-1; TGF- $\alpha$, Transforming Growth Factor- $\alpha$; uNK, uterine natural killer cells.

Figure 2. Schematic diagram of melatonin on circadian cycle during pregnancy.

\section{$432 \times 460 \mathrm{~mm}(150 \times 150 \mathrm{DPI})$}


Physical Stress, Psychological Disturbance, Circadian Disturbance, Environmental Cues

Mother

Placenta

Fetus

个Placenta Permeability , 个Apoptotic Activity, $\downarrow$ Immunity, $\downarrow$ Vascularization

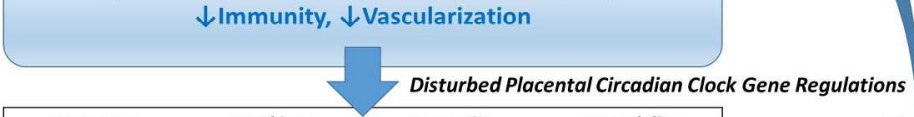

\section{Hormones Cytokines}

- Melatonin - IL-1

- Glucocorticoids - IL-4

- hPL

- IL-4

- IL-10

- hCG ROS

- $N F-K B$

- TGF- $\alpha$ families

- Macrophages - VEGF

- Macrophages

Cells

- T-regulatory

- Endothelial Cells
Neuron

Cells

Development
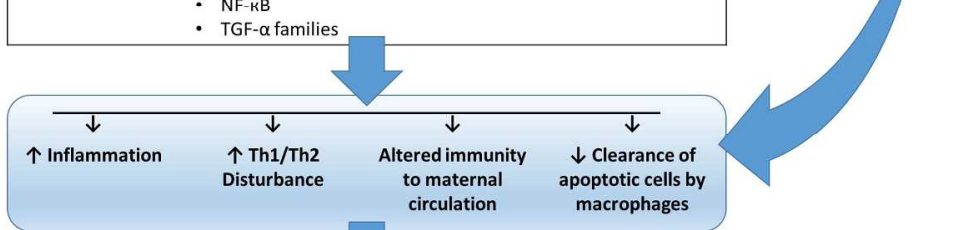

Pregnancy
Outcomes

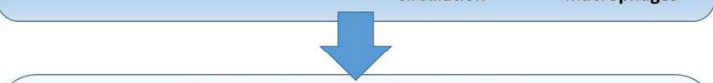

Intrauterine growth restriction

Preterm Birth

Developmental Programming

Growth Defects

Preeclampsia

Gestational Diabetes Infection

Figure 3. Illustration on the effect of clock genes regulation during pregnancy and their subsequent role in clinical pathology.

IGF1, insulin-like growth factor; IGF2, insulin-like growth factor; EGF, epidermal growth factor; PDGF, PlateletDerived Growth Factor; FGF-2, Fibroblast Growth Factor-2; FGF-2, Fibroblast Growth Factor-4; TGF- $\beta$, Transforming Growth Factor- $\beta$; IL-1, Interleukin-1; IL-4, Interleukin-4; IL-6, Interleukin-6; IL-10, Interleukin-10; ROS, Reactive Oxygen Species; NF-KB, nuclear factor kappa-light-chain-enhancer of activated B cells; TGF- $\alpha$, Transforming Growth Factor- $\alpha$

Figure 3. Illustration on the effect of clock genes regulation during pregnancy and their subsequent role in clinical pathology.

$409 \times 483 \mathrm{~mm}(150 \times 150 \mathrm{DPI})$ 